\title{
CCR5 $\Delta 32$ Polymorphism Associated with a Slower Rate Disease Progression in a Cohort of RR-MS Sicilian Patients
}

\author{
Rosalia D’Angelo, Concetta Crisafulli, Carmela Rinaldi, Alessia Ruggeri, \\ Aldo Amato, and Antonina Sidoti
}

Department of Biomorphology and Biotechnologies, University of Messina, 98125 Messina, Italy

Correspondence should be addressed to Concetta Crisafulli, ccrisafulli@unime.it

Received 15 November 2010; Accepted 19 February 2011

Academic Editor: Oscar Fernandez

Copyright (c) 2011 Rosalia D’Angelo et al. This is an open access article distributed under the Creative Commons Attribution License, which permits unrestricted use, distribution, and reproduction in any medium, provided the original work is properly cited.

Multiple sclerosis (MS) disease is carried through inflammatory and degenerative stages. Based on clinical feaures, it can be subdivided into three groups: relapsing-remitting MS, secondary progressive MS, and primary progressive MS. Multiple sclerosis has a multifactorial etiology with an interplay of genetic predisposition, environmental factors, and autoimmune inflammatory mechanism in which play a key role CC-chemokines and its receptors. In this paper, we studied the frequency of CCR5 gene $\Delta 32$ allele in a cohort of Sicilian RR-MS patients comparing with general Sicilian population. Also, we evaluate the association between this commonly polymorphism and disability development and age of disease onset in the same cohort. Our results show that presence of CCR5 32 is significantly associated with expanded disability status scale score (EDSS) but not with age of disease onset.

\section{Introduction}

Multiple sclerosis (MS) is a autoimmune chronic disorder of the central nervous system (CNS) characterized by multifocal inflammatory destruction of myelin, axonal damage, loss of oligodendrocytes, and repair mechanism [1].

MS is a frightening and potentially disabling disease for young adults that afflicts around 2.5 million people worldwide with an incidence of about 7 per 100,000 persons every year, a prevalence of around 120 per 100,000 , and a lifetime risk of 1 in 400 [2].

Studies of MS-twin pairs have revealed that the estimated concordance for MS was 3\%-5\% for dizygotic and 25\%-30\% for monozygotic twins $[3,4]$.

On the basis of the temporal course of disease, MS can be subdivided into three clinical groups: relapsing-remitting MS (RR-MS, characterized by relapses when there is a flare up of symptoms, followed by remissions when there are not symptoms), secondary progressive MS (SP-MS, a slow and gradual form that begins with a relapsing-remitting course), and primary progressive MS (PP-MS, which is expressed, from the start, by a gradual progression of disability). The most common form of disease in approximately $85 \%$ of the cases is RR-MS and, typically, the illness passes through phases of relapse with full recovery, relapse with persistent deficit, and secondary progression $[1,2]$. Patients with RR-MS accumulate disability from disease onset more slowly than those with primary progressive multiple sclerosis. Most therapeutic agents used in MS (e.g., immunosuppressive and immunomodulatory drugs and cell-cycle interruption drugs) are only used for RR-MS. These treatments show some efficiency in lessening the relapse rate in RR-MS and time to progression but cannot cure MS. Thus, there is a need for new efficient treatments for all types of MS [5]. The etiology of MS is unknown but likely multifactorial, with an interplay of genetic predisposition, environmental factors and autoimmune inflammatory mechanism; in fact, this disease is carried through two stages: inflammatory and degenerative $[6,7]$. The migration of inflammatory cells is facilitated by the upregulation of adhesion molecules-1 (ICAM-1), vascular-cell adhesion molecules-1 (VCAM-1), and platelet endothelial cell adhesion molecule-1 (PECAM-1) [8]. On 
the other hand, matrix metalloproteinases (MMPs) may degrade components of the basement membrane, and chemokines can form concentration gradient, which attract leukocytes and activate leukocyte integrins, increasing adherence and extravasation [9]. Then, the proinflammatory cytokines (e.g., TNF-a, INF-g, IL-2, and IL-12) released by Th 1 cells and macrophages trigger a chain of events, resulting in the formation of demyelinated plaque and damage to axon $[8,10,11]$. Activated $\mathrm{T}$ cells enter the CNS and trigger an inflammatory cascade that leads to recruitment of other immune cells. Increasing lines of evidence have implicated an involvement for chemokines and their receptors in several neurodegenerative disorders, including Alzheimer's disease (AD), Parkinson's disease (PD), HIVassociated dementia (HAD), and also in multiple sclerosis (MS) [12]. Genetic studies indicate that CC-chemokines and chemokine receptors are involved in the susceptibility to MS [13], in fact; they play a significant role in the migration of monocytes and T cells. In particular, CC-chemokine receptor 5 (CCR5), a seven-transmembrane spanning G proteincoupled receptor, is a specific binding site for the CCchemokines like RANTES (CCL5), macrophage inflammatory protein MIP $1 \alpha$ (CCL3), and macrophage inflammatory protein MIP $1 \beta$ (CCL4) [14]. CCR5 encoded by CCR5 gene, located on chromosome 3p21 [15], has been identified as a coreceptor for the human immunodeficiency virus-1 (HIV-1) [16]. A nonfunctional allele, resulting from a 32bp deletion in exon 4, CCR $5 \Delta 32$, leads to a truncated form of the functional receptor. Individuals homozygous for a 32 -bp deletion allele of CCR5, CCR $5 \Delta 32$, were resistant to HIV-1 infection despite repeated exposure [14]. Moreover, in the CNS, CCR5 is expressed on neurons, astrocytes, and microglia [17], as well as on endothelium and vascular smooth muscle cells and on T-helper cells [18]. During MS pathogenesis, the absence of functional CCR5 on the cell surface could lead to reduced trafficking of leucocytes into the lesion sites, thus downregulating inflammation in brain tissue. To assess the possible association between CCR $5 \Delta 32$ and the course of MS, various studies were performed, and while several studies showed an association between CCR5 432 and a favorable clinical course of MS [19-21], no correlation was found between this polymorphism and the course of the disease in other studies [22-24]; however, the results are in contrast and are not yet clear [25]. Based upon the key role played by chemokines in the migration of macrophages and T cells in MS, and the importance of genetic factors associated and the possible viral or nonviral stimulation involved in the pathogenesis of the disease, in this work, we investigated the effect of CCR $5 \Delta 32$ on age of onset, course, and severity of disease in cohort of Sicilian patients with RR-MS.

\section{Materials and Methods}

2.1. Patient Samples. Peripheral blood specimens were obtained from 180 RR-MS patients (131 female and 49 male) recruited from the Department of Neurosciences, Psychiatric and Anaesthesiological Sciences, University of Messina, Italy.
All patients in this study fulfilled the criteria for clinically defined MS [26] and underwent routine diagnostic CSF and blood tests, and a full neurological examination. At the time of sample collection, disease type was defined as relapsing-remitting MS (RR-MS) disease, with Kurtzke expanded disability status scale scores between 0.0 and 6.5 (EDSS-expanded disability status scale or disease progression index).

Control group comprised 213 unrelated, healthy donors without a family history of autoimmune diseases and were collected during field studies conducted in 1999 and 2005. The samples were taken from several towns in Sicily.

The individual donors were eligible for the present study if their ancestors were born in the same location and if they had no progenitors in common up to their grandparental generation.

All parameters (age, age at onset, and EDSS) of male versus female were matched in the MS patient group as well as the age of male versus female in the controls. All participants gave their written informed consent.

2.2. Genotyping. Genomic DNA was isolated using the salting out method [27].

Eparinized peripheral blood was collected from cases and controls before any therapy. PCR was carried out in a thermal cycler (Gene Amp PCR System 9600; PE Applied Biosystems, Foster City, CA) in $50 \mu \mathrm{L}$ volumes containing a $0.2 \mu \mathrm{m}$ concentration of each primer (forward CCR5 primer: 5'-GTCTTCATTACACCTGCAGCTC; reverse: 5' GTGAAGATAAGCCTCACAGCC), 1U Euro Taq polymerase (Euroclone Spa Life Sciences Division, Italy) and $0.8 \mu \mathrm{g}$ genomic DNA as template, under the following conditions: denaturation at $95^{\circ} \mathrm{C}$ for $1.5 \mathrm{~min}$, annealing at $56.5^{\circ} \mathrm{C}$ for $1 \mathrm{~min}$ and extension at $72^{\circ} \mathrm{C}$ for $50 \mathrm{~s}$ for 35 cycles, after an initial $5 \mathrm{~min}$ denaturation at $95^{\circ} \mathrm{C}$. Aliquot of the PCR products were separated using agarose gel electrophoresis, and the $198 \mathrm{bp}$ in the case of the wild-type allele and $166 \mathrm{bp}$ in the case of the $\Delta 32$ allele were visualized using ultraviolet light, following ethidium bromide staining.

2.3. Statistical Analysis. For each group (control and patients), the CCR $5 \Delta 32$ allele frequencies were calculated by direct gene counting. Statistical analyses were performed using "Statistica" package [28]. Data are presented as mean \pm $\mathrm{SD}$ for parametric variables and as percentages for nonparametric values. Continuous variables were compared using Student's $t$-test to test possible influence of CCR $5 \Delta 32$ allele on EDSS score and age onset. With the aim of reducing possible sources of variance, we included in our analyses gender, age, and age at disease onset as covariates using ANOVA method for statistical analysis. All $P$ values were 2tailed, and statistical significance was set at $P<.05$.

\section{Results}

The demographic data are reported in Table 1 which indicates no significant differences $(P<.05)$ between overall MS age versus overall healthy control age. The frequencies 
TABle 1: Demographic and disease-related data of our samples.

\begin{tabular}{|c|c|c|c|c|c|}
\hline & Gender & $n$ & $\begin{array}{c}\text { Age } \\
\text { Mean } \pm \text { SD }\end{array}$ & $\begin{array}{l}\text { Age of onset } \\
\text { Mean } \pm \text { SD }\end{array}$ & $\begin{array}{l}\text { EDSS at time of examination } \\
\text { Mean } \pm \text { SD }\end{array}$ \\
\hline \multirow[t]{5}{*}{ MS patients } & Male & $49(27 \%)$ & $45.4 \pm 7.7$ & $29.1 \pm 7.6$ & $2.3 \pm 1.7$ \\
\hline & Female & $131(73 \%)$ & $44.6 \pm 8.2$ & $29.5 \pm 7.9$ & $2.7 \pm 1.1$ \\
\hline & Overall & 180 & $44.8 \pm 8.0$ & $29.4 \pm 7.8$ & $2.6 \pm 1.3$ \\
\hline & GFNDFR & $n$ & & AGE & \\
\hline & ULIVDLT & $n$ & & Mean \pm SD & \\
\hline \multirow{3}{*}{ Healthy controls } & Male & $61(29 \%)$ & & $45 \pm 12$ & \\
\hline & Female & $152(71 \%)$ & & $43 \pm 11$ & \\
\hline & Overall & 213 & & $44 \pm 11.4$ & \\
\hline
\end{tabular}

MS: multiple sclerosis; EDSS: expanded disability status scale; SD: standard deviation. $P<.05$ indicates statistical significance.

of CCR5 $\Delta 32$ alleles in patients with MS $(f r=0.06)$ did not differ significantly from those of controls $(f r=0.06)$ and were not influenced by gender $\left(\chi^{2}=2.00, P=.13\right)$. We observed a significant association between CCR5 $\Delta 32$ allele and EDSS scores $(t=2.04, P<.05)$. As a consequence, for reducing possible sources of variance, we introduced all such variables as covariates in our model. Data showed that introducing sex, age, and age of onset as covariates, results remain statistically significant. We did not observed any significant association between CCR $5 \Delta 32$ allele and age onset $(P>.05)$ (Table 2$)$.

\section{Discussion}

Chemokine receptors and their ligands play a key role in several neurodegenerative diseases, such as MS, when they are activated inappropriately [34]. The chemokine receptors expressed by $\mathrm{T}$ helper cells may be important reports allowing the association between multiple sclerosis and CNS infiltrated CD4 cells and monocytes. For this reason, it seems that these receptors may be related to the development of new lesions in multiple sclerosis [35].

In addition in a T-cell-mediated inflammatory disease like MS, the expression of chemokines and their receptors is markedly regulated by proinflammatory cytokines, for example, tumour necrosis factors or interleukins [36]. All these evidences are also confirmed by various studies that showing an elevated expression of CC-chemokine in the CNS in MS patients: researchers have focused on chemokine receptor, their ligands, and they have highlighted the role they have played in the development and clinical course of MS [37-39]. In particular, the role of CCR5 in MS is further strengthened by recent finding of elevated CCR5 levels in CD8(+) cells in MS patients [36].

From our study, it was found that the CCR5 $\Delta 32$ allele frequency in Sicilian RR-MS patients $(f r=0.06)$ is comparable to that found in the general population $(f r=$ 0.06) [40]. Our results, on the one hand, are consistent with those of some studies [20] and, on the other hand, are not confirmed by other studies $[29,31]$.

In fact, Otaegui et al. reported a lower frequency of the CCR5 $\triangle 32$ allele in MS patients compared with the control population in Basque, Spain [31]. Indeed, in the Iranian population, Shahbazi et al. demonstrated that the $\Delta 32$ allele frequency was higher among MS patients than in control [29]. These conflicting data may result from several factors as sample size, environmental factors, and differences in ethnicity [41].

With regard to the association $\triangle 32 \mathrm{CCR} 5$ allele and clinical course of MS the data in the literature are conflicting. In fact, various studies described an association of the $\triangle 32$ CCR5 allele with a favorable clinical course of MS [19-21], while others have failed to show any significant correlation between this polymorphism and the course of the disease $[22,23]$ (an overview of main association studies is summarized in Table 3 ). Our data showed an association of the CCR5 $\triangle 32$ allele with expanded disability status scale score $(t=2.04, P<.05)$ in RR-MS patients, suggesting that its presence contributes to a slower rate of disease progression. From these results appears a lower expression of a functional CCR5 receptor that might influence the rate of disability development, and then harboring the mutated CCR5 allele can be considered a favorable prognostic factor in MS.

However, as opposed to another recent report [19], we did not find a difference in the age at disease onset between the $\triangle 32$ CCR5 carriers and noncarriers $(P>.05)$. In our opinion, it is important to note that the data shown in this work are not influenced by factors such as age, age of onset disease, and gender (see at the results in Table 2).

Overall, the genetic susceptibility to MS remains an open question. Much of the future research interest will focus to better understand the genetic heterogeneity of this disease and the therapeutic needs individual though the replication of candidate gene association analysis is difficult in MS as is often happens with complex genetic diseases. The broad system of chemokines and their receptors may be an important key in the search for answers to these questions. More studies are needed to reveal the exact role of chemokine network and its association with other factors in the pathogenesis of this disease. Our data suggest that the presence of this CCR5 polymorphism in patients with RR-MS might help in designing a therapeutic regimen and might serve as a prognostic marker and then that CCR5 antagonists could be considered potential targets for therapeutic intervention in MS. 


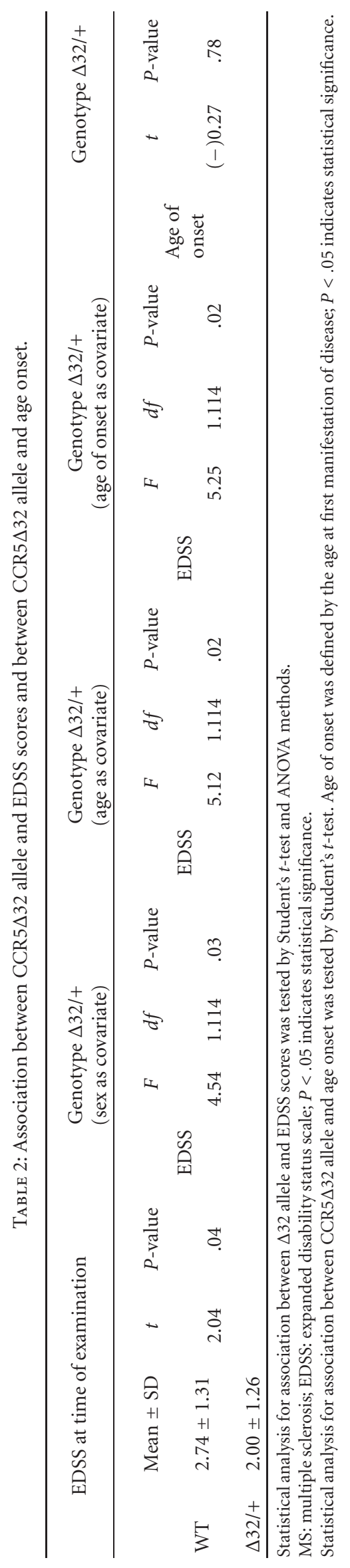


TABLE 3: Overview of major association studies.

\begin{tabular}{|c|c|c|c|c|}
\hline Patients country & Clinical variable & Statistical method & Results & References \\
\hline Iran & MS development & ANOVA & Yes (predisposing factor) & [29] \\
\hline Brazil & Age of onset; EDSS & $\begin{array}{l}\text { ANOVA; chi-square test; } \\
\text { Mann-Whitney } U \text {-test }\end{array}$ & $\begin{array}{l}\text { Potential favorable } \\
\text { prognostic biomarker }\end{array}$ & {$[25]$} \\
\hline Denmark & EDSS & Mann-Whitney $U$-test & No associations & {$[30]$} \\
\hline Spain & $\begin{array}{l}\text { Etiopathogeny of the } \\
\text { disease }\end{array}$ & Not available & Yes (protective role) & {$[31]$} \\
\hline Croatia; Slovenia & $\begin{array}{l}\text { Age of disease onset or } \\
\text { progression of the disease }\end{array}$ & Not available & No associations & {$[23]$} \\
\hline USA & Age of onset; EDSS & Student's $t$-test; ANOVA & No associations & {$[22]$} \\
\hline Northern Ireland & $\begin{array}{l}\text { Age of onset; } \\
\text { susceptibility to develop } \\
\text { MS }\end{array}$ & Not available & No associations & {$[24]$} \\
\hline Finland & $\begin{array}{l}\text { Susceptibility to develop } \\
\text { MS }\end{array}$ & chi-square test; ANOVA & No associations & {$[32]$} \\
\hline Israel & EDSS & Not available & $\begin{array}{l}\text { Potential favorable } \\
\text { prognostic biomarker }\end{array}$ & {$[20]$} \\
\hline Germany & $\begin{array}{l}\text { Susceptibility to develop } \\
\text { MS }\end{array}$ & ANOVA & No associations & {$[33]$} \\
\hline USA & Age of onset & Not available & $\begin{array}{l}\text { Age of onset was } \\
\text { approximately } 3 \text { years later } \\
\text { in patients carrying the } \\
\text { CCR } 532 \text { deletion }\end{array}$ & {$[19]$} \\
\hline Denmark & $\begin{array}{l}\text { Susceptibility to develop } \\
\text { MS }\end{array}$ & ANOVA; Student's $t$-test & Lower risk & {$[21]$} \\
\hline
\end{tabular}

\section{Acknowledgments}

The authors thank all the participants who made this study possible. The authors are also thankful to the Departement of Neuroscience, Psychiatric and Anestesiological Sciences, University of Messina, who helped them in recruiting patients with multiple sclerosis.

\section{References}

[1] M. Bosnjak-Pasić, B. Vidrih, S. Miskov, and V. Demarin, "Treatment of multiple sclerosis," Acta Clinica Croatica, vol. 48, no. 3, pp. 349-353, 2009.

[2] A. Compston and A. Coles, "Multiple sclerosis," Lancet, vol. 359, no. 9313, pp. 1221-1231, 2002.

[3] T. Hansen, A. Skytthe, E. Stenager, H. C. Petersen, H. Brønnum-Hansen, and K. O. Kyvik, "Concordance for multiple sclerosis in Danish twins: an update of a nationwide study," Multiple Sclerosis, vol. 11, no. 5, pp. 504-510, 2005.

[4] C. J. Willer, D. A. Dyment, N. J. Risch et al., "Twin concordance and sibling recurrence rates in multiple sclerosis," Proceedings of the National Academy of Sciences of the United States of America, vol. 100, no. 22, pp. 12877-12882, 2003.

[5] J. Yan and J. M. Greer, "NF- $\kappa$ B, a potential therapeutic target for the treatment of multiple sclerosis," CNS and Neurological Disorders, vol. 7, no. 6, pp. 536-557, 2008.

[6] M. Pugliatti, H. F. Harbo, T. Holmøy et al., "Environmental risk factors in multiple sclerosis," Acta Neurologica Scandinavica, vol. 117, no. 188, pp. 34-40, 2008.

[7] S. V. Ramagopalan, G. C. DeLuca, A. Degenhardt, and G. C. Ebers, "The genetics of clinical outcome in multiple sclerosis,"
Journal of Neuroimmunology, vol. 201-202, pp. 183-199, 2008.

[8] R. M. Ransohoff, "Mechanisms of inflammation in MS tissue: adhesion molecules and chemokines," Journal of Neuroimmunology, vol. 98, no. 1, pp. 57-68, 1999.

[9] F. Sellebjerg and T. L. Sørensen, "Chemokines and matrix metalloproteinase-9 in leukocyte recruitment to the central nervous system," Brain Research Bulletin, vol. 61, no. 3, pp. 347-355, 2003.

[10] J. Imitola, T. Chitnis, and S. J. Khoury, "Cytokines in multiple sclerosis: from bench to bedside," Pharmacology and Therapeutics, vol. 106, no. 2, pp. 163-177, 2005.

[11] B. M. Segal, "CNS chemokines, cytokines, and dendritic cells in autoimmune demyelination," Journal of the Neurological Sciences, vol. 228, no. 2, pp. 210-214, 2005.

[12] L. Cartier, O. Hartley, M. Dubois-Dauphin, and K. H. Krause, "Chemokine receptors in the central nervous system: role in brain inflammation and neurodegenerative diseases," Brain Research Reviews, vol. 48, no. 1, pp. 16-42, 2005.

[13] T. Vyshkina, Y. Y. Shugart, G. Birnbaum, T. P. Leist, and B. Kalman, "Association of haplotypes in the $\beta$-chemokine locus with multiple sclerosis," European Journal of Human Genetics, vol. 13, no. 2, pp. 240-247, 2005.

[14] M. Samson, F. Libert, B. J. Doranz et al., "Resistance to HIV-1 infection in caucasian individuals bearing mutant alleles of the CCR-5 chemokine receptor gene," Nature, vol. 382, no. 6593, pp. 722-726, 1996.

[15] R. Liu, W. A. Paxton, S. Choe et al., "Homozygous defect in HIV-1 coreceptor accounts for resistance of some multiplyexposed individuals to HIV-1 infection," Cell, vol. 86, no. 3, pp. 367-377, 1996. 
[16] H. Deng, R. Liu, W. Ellmeier et al., "Identification of a major co-receptor for primary isolates of HIV-1," Nature, vol. 381, no. 6584, pp. 661-666, 1996.

[17] R. Bonecchi, G. Bianchi, P. P. Bordignon et al., "Differential expression of chemokine receptors and chemotactic responsiveness of type $1 \mathrm{~T}$ helper cells (Th1s) and Th2s," Journal of Experimental Medicine, vol. 187, no. 1, pp. 129-134, 1998.

[18] J. B. Rottman, K. P. Ganley, K. Williams, L. Wu, C. R. Mackay, and D. J. Ringler, "Cellular localization of the chemokine receptor CCR5: correlation to cellular targets of HIV-1 infection," American Journal of Pathology, vol. 151, no. 5, pp. 1341-1351, 1997.

[19] L. F. Barcellos, A. M. Schito, J. B. Rimmler et al., "CC-chemokine receptor 5 polymorphism and age of onset in familial multiple sclerosis," Immunogenetics, vol. 51, no. 4-5, pp. 281288, 2000.

[20] R. Kantor, M. Bakhanashvili, and A. Achiron, "A mutated CCR5 gene may have favorable prognostic implications in MS," Neurology, vol. 61, no. 2, pp. 238-240, 2003.

[21] F. Sellebjerg, H. O. Madsen, C. V. Jensen, J. Jensen, and P. Garred, "CCR5 $\Delta 32$, matrix metalloproteinase-9 and disease activity in multiple sclerosis," Journal of Neuroimmunology, vol. 102, no. 1, pp. 98-106, 2000.

[22] O. H. Kantarci, Y. Morales, P. A. Ziemer et al., "CCR5 $\Delta 32$ polymorphism effects on CCR5 expression, patterns of immunopathology and disease course in multiple sclerosis," Journal of Neuroimmunology, vol. 169, no. 1-2, pp. 137-143, 2005.

[23] S. Ristić, L. Lovrečić, N. Starčevié-Čizmarević et al., "No association of CCR $5 \Delta 32$ gene mutation with multiple sclerosis in Croatian and Slovenian patients," Multiple Sclerosis, vol. 12, no. 3, pp. 360-362, 2006.

[24] J. A. Silversides, S. V. Heggarty, G. V. McDonnell, S. A. Hawkins, and C. A. Graham, "Influence of CCR5 $\delta 32$ polymorphism on multiple sclerosis susceptibility and disease course," Multiple Sclerosis, vol. 10, no. 2, pp. 149-152, 2004.

[25] D. R. Kaimen-Maciel, E. M. Vissoci Reiche, D. G. Brum Souza et al., "CCR5-Delta32 genetic polymorphism associated with benign clinical course and magnetic resonance imaging findings in Brazilian patients with multiple sclerosis," International Journal of Molecular Medicine, vol. 20, no. 3, pp. 337-344, 2007.

[26] C. M. Poser, D. W. Paty, and L. Scheinberg, "New diagnostic criteria for multiple sclerosis: guidelines for research protocols," Annals of Neurology, vol. 13, no. 3, pp. 227-231, 1983.

[27] J. Sambrook, E. F. Fritsch, and T. Maniatis, Molecular Cloning: Alboratory Manual, Cold Spring Harbour Laboratory, New York, NY, USA, 2nd edition, 1989.

[28] I. StatSoft, "Statistica per Windows," StatSoft Italia srl, 1995.

[29] M. Shahbazi, H. Ebadi, D. Fathi et al., "CCR5-Delta32 allele is associated with the risk of developing multiple sclerosis in the Iranian population," Cellular and Molecular Neurobiology, vol. 29, no. 8, pp. 1205-1209, 2009.

[30] F. Sellebjerg, T. B. Kristiansen, P. Wittenhagen et al., "Chemokine receptor CCR5 in interferon-treated multiple sclerosis," Acta Neurologica Scandinavica, vol. 115, no. 6, pp. 413-418, 2007.

[31] D. Otaegui, J. Ruíz-Martínez, J. Olaskoaga, J. I. Emparanza, and A. L. De Munain, "Influence of CCR5- $\Delta 32$ genotype in Spanish population with multiple sclerosis," Neurogenetics, vol. 8, no. 3, pp. 201-205, 2007.

[32] M. Luomala, T. Lehtimäki, H. Huhtala et al., "Promoter polymorphism of IL-10 and severity of multiple sclerosis," Acta Neurologica Scandinavica, vol. 108, no. 6, pp. 396-400, 2003.
[33] C. G. Haase, S. Schmidt, and P. M. Faustmann, "Frequencies of the G-protein $\beta 3$ subunit C825T polymorphism and the $\delta 32$ mutation of the chemokine receptor-5 in patients with multiple sclerosis," Neuroscience Letters, vol. 330, no. 3, pp. 293-295, 2002.

[34] C. Gerard and B. J. Rollins, "Chemokines and disease," Nature Immunology, vol. 2, no. 2, pp. 108-115, 2001.

[35] M. J. Eikelenboom, J. Killestein, T. Izeboud et al., "Chemokine receptor expression on T cells is related to new lesion development in multiple sclerosis," Journal of Neuroimmunology, vol. 133, no. 1-2, pp. 225-232, 2002.

[36] B. R. Lane, D. M. Markovitz, N. L. Woodford, R. Rochford, R. M. Strieter, and M. J. Coffey, "TNF- $\alpha$ inhibits HIV-1 replication in peripheral blood monocytes and alveolar macrophages by inducing the production of RANTES and decreasing C-C chemokine receptor 5 (CCR5) expression," Journal of Immunology, vol. 163, no. 7, pp. 3653-3661, 1999.

[37] J. Simpson, P. Rezaie, J. Newcombe, M. L. Cuzner, D. Male, and M. N. Woodroofe, "Expression of the $\beta$-chemokine receptors CCR2, CCR3 and CCR5 in multiple sclerosis central nervous system tissue," Journal of Neuroimmunology, vol. 108, no. 1-2, pp. 192-200, 2000.

[38] P. A. Calabresi, R. Martin, and S. Jacobson, "Chemokines in chronic progressive neurological diseases: HTLV-1 associated myelopathy and multiple sclerosis," Journal of Neurovirology, vol. 5, no. 1, pp. 102-108, 1999.

[39] T. Strunk, S. Bubel, B. Mascher, P. Schlenke, H. Kirchner, and K. P. Wandinger, "Increased numbers of CCR5+ interferon$\gamma$ - and tumor necrosis factor- $\alpha$ - secreting T lymphocytes in multiple sclerosis patients," Annals of Neurology, vol. 47, no. 2, pp. 269-273, 2000.

[40] A. Sidoti, R. D'Angelo, C. Rinaldi et al., "Distribution of the mutated $\Delta 32$ allele of the CCR5 gene in a Sicilian population," International Journal of Immunogenetics, vol. 32, no. 3, pp. 193-198, 2005.

[41] A. Sidoti, R. Robledo, A. Rinaldi, R. D’Angelo, C. Rinaldi, and A. Amato, "Further data on a 9.1-kb insertion-deletion polymorphism: survey of mediterranean populations," Human Biology, vol. 78, no. 3, pp. 371-378, 2006. 


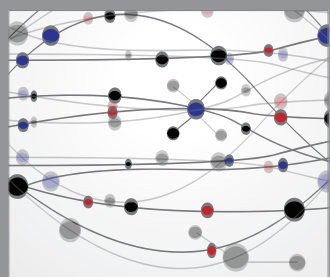

The Scientific World Journal
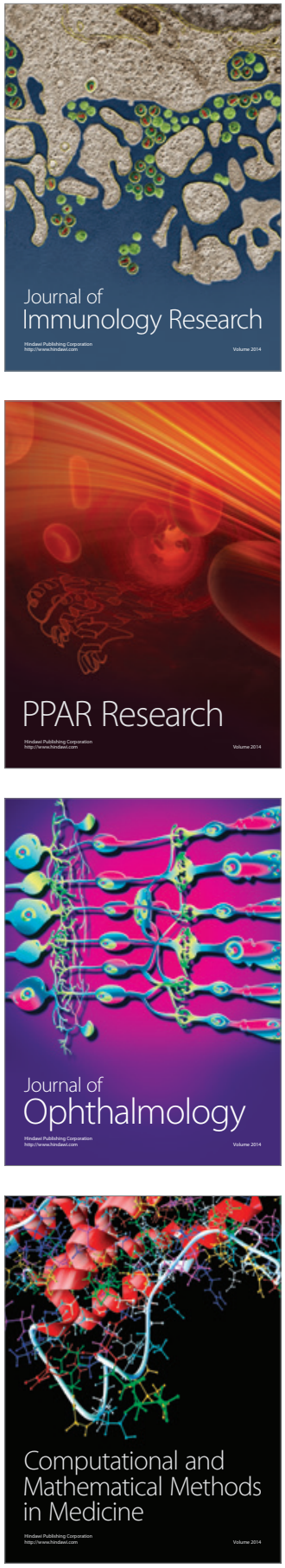

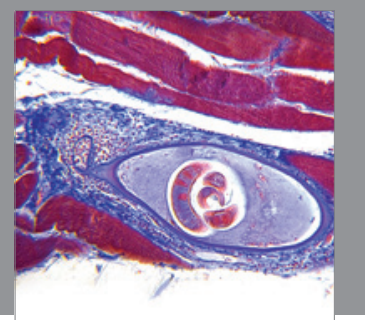

Gastroenterology

Research and Practice
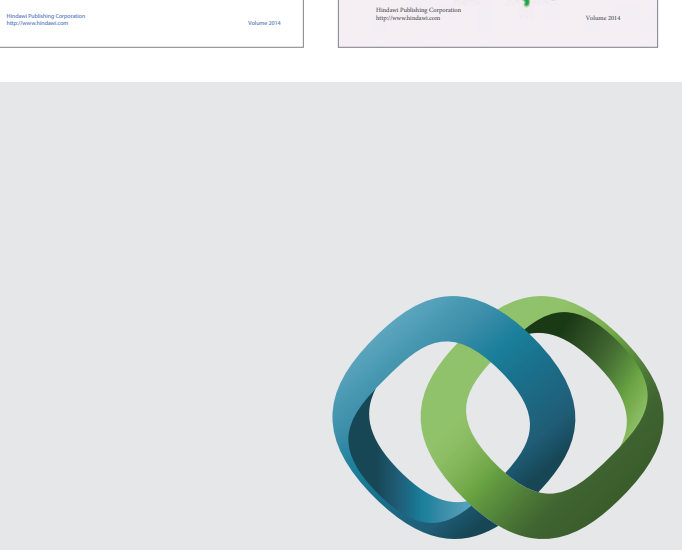

\section{Hindawi}

Submit your manuscripts at

http://www.hindawi.com
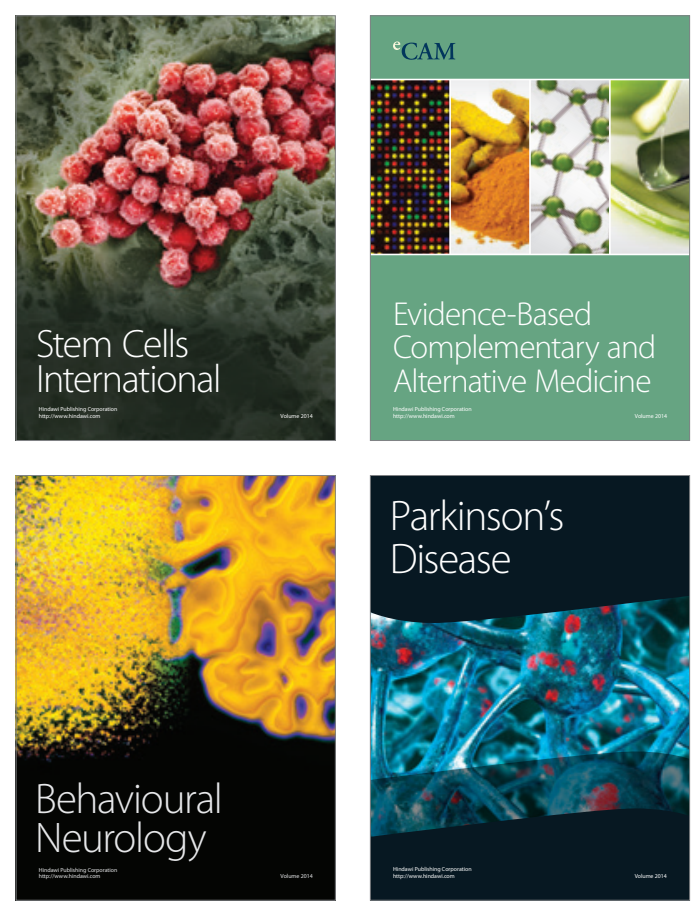

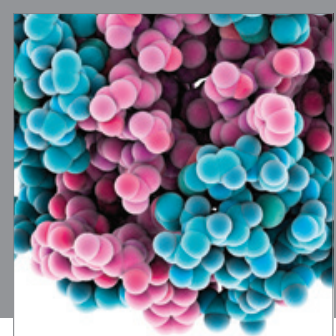

Journal of
Diabetes Research

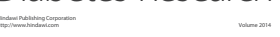

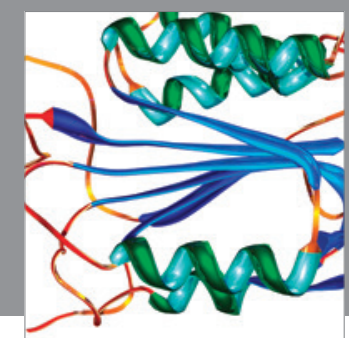

Disease Markers
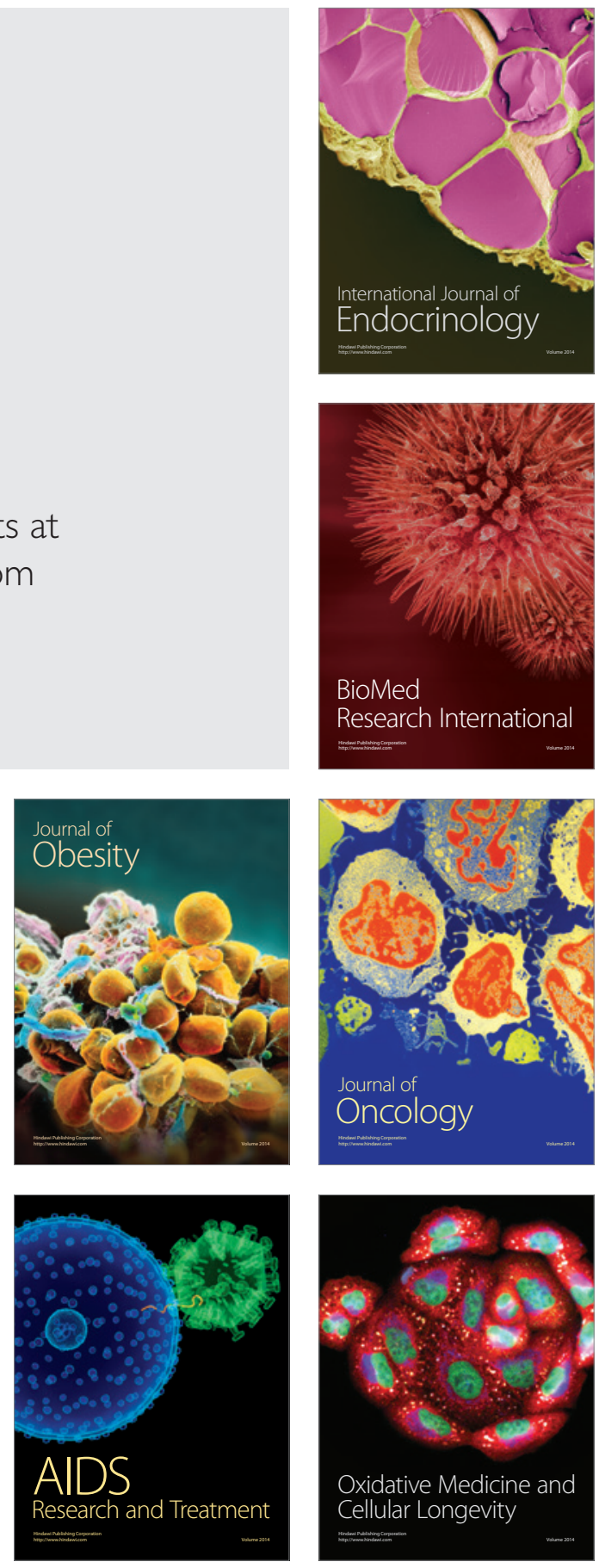